\title{
Some Perspectives on History and Philosophy of Science in the Baltic Region
}

This issue starts already the third year of the existence of the open-access peerreviewed journal Acta Baltica Historiae et Philosophiae Scientiarum (ABHPS). During this period, the principles of editorial work, including, first of all, procedures for arranging peer review, communication with existing and prospective authors, elaboration of technical details, the structure of journal, etc. have been developed. The main principles of editorial policy and methods, including the arrangement of peer review, have been described in the editorials of our four past issues (Müürsepp \& Talts, 2013a, b; 2014a, b). We believe that there is no need to revisit these questions again and we advise anyone interested to read them carefully. There is just one small change: the length restriction on articles published in the section 'Short Communications' (see the 'Style Guide' in the back of the current issue) has been extended to seven pages (18,000 characters).

The journal's mission: The main purpose of $A B H P S$, like that of any other scientific journal, is to publish quality papers in respective fields and thus promote the exchange of ideas and information, creating conditions for fruitful international cooperation between scholars active in the field. During the last two and a half years that $A B H P S$ has been published, the journal has established its place in the field and is developing on a desired course at an expected pace. We see it as our mission to contribute to the internationalization process of Baltic research in the fields of history and philosophy of science (HPS). Since the possibilities of scholars from the Baltic states are quite limited in terms of becoming professionally involved in the fields of the HPS in the strictest sense of the expression (i.e. to be employed as historians and/ or philosophers of science), the journal intends to contribute to increasing their professional skills otherwise (by publishing the best examples of scientific research in the fields and improving quality of papers through peer reviewing process, etc.). We continue to double check the quality of articles submitted through rigorous and unconditional double-blind peer review by two or more referees, although we are aware of the problems related to its implementation, especially in the Baltic countries, where the ranks of specialists in almost every field are extremely narrow. Therefore, a combination of international and local expertise is of vital importance for our journal. 
We continue to pay special interest to contributions which try to bring two seemingly distinct fields - history of science and philosophy of science-closer together. In our previous issues we have had an opportunity to publish a couple of such papers, among them an article by Joseph Agassi (2014). This will hopefully be continued in the forthcoming issues of ABHPS. Our aim is to get closer to having a journal that would be classified as an HPS journal, rather than a publication which addresses the fields of history of science and philosophy of science separately. In addition, papers that belong to HOPOS (history of philosophy of science) remain to be welcomed as well. Thus, we continue to give quality the priority over disciplinary purity.

Problems: Since ABHPS is an open access journal without a publication charge or Article Processing Charge (APC), we depend entirely on the support of scientific organizations, first of all Estonian Association for the History and Philosophy of Science and the Department of International Relations of the Tallinn University of Technology (TUT). The editorial office has received also some significant private donations (e.g., from Alīda Zigmunde, Winfried Julius Schoeller, Ramūnas Kondratas, and others) for which we are deeply grateful. The Chair of Philosophy of TUT has provided the journal its support, both moral and financial. Still, creation of a solid financial basis for the journal remains one of the top priorities of the editorial team.

One of the current problems is the rather modest reputation of history of science in the Baltic states. There are no specific doctorate programs on history of science and quite often people specialize in history of science when they reach middle age or beyond. As far as philosophy of science is concerned, the number of people working as philosophers of science is quite high for such a small country as Estonia (there are currently more than ten individuals employed entirely or partially as philosophers of science in Estonia). Still, making the field of the HPS ever more attractive for the young people, so that they could specialize in it already at the beginning of their professional career, is one of the purposes, or raisons d'etre, of ABHPS. In other words, the editorial team of the journal is willing to do everything in order to ensure the sustainability of the field of HPS in the Baltic countries and make sure that young people find the HPS attractive enough for their professional career.

Prospective developments: On the one hand, our journal intends to contribute to enhancing the academic level of publications, to expanding the geographical scope of the authors and the audience of the journal. We are pleased to see 
that the journal's geographical range of authors has grown beyond the limits of Europe to North America, Israel and, with Yao Dazhi's contribution in the current issue, also to China. Next to all the countries of the Baltic Rim (Estonia, Latvia, Lithuania, Finland, Sweden, Denmark, Poland, Germany, Russia), the journal has so far published articles by scholars from the Netherlands, France, Belarus, Ukraine, USA, Israel, and China.

At the same time, it seems that the journal can afford to expand its scope in a reasonable manner. In the future, we hope to receive articles on the philosophical aspects of social sciences. Social studies of science, including sociology of science, as well as social context studies, or the area that could be referred as "societal element of science" (Riesch, 2014, p. 30), is an important branch of study worth including in our journal. It is obvious that science (this concerns all fields of science: natural, exact, and social sciences) evolve in a certain social and historical context which directly influences the interpretations of findings (this is more evident in terms of social studies, but not completely irrelevant in terms of natural sciences either). In addition, we look forward to more contributions in the fields of history of sociology, psychology, linguistics, and other soft disciplines. The same applies to the history of economics (i.e. economic thought) and the history of technology (incl. technological thinking). Although we accept factographic studies, which certainly are worthy of attention, priority would still be given to contributions concerning the history of ideas, including the influences of both internal and external factors on the latter.

In the future, hopefully already in our next issue, we intend to promote the principal discussion by offering publication opportunities to contributions of polemic nature. We also welcome more contributions in the fields of the philosophy and methodology of social science and the humanities, but also articles addressing the historical contexts of scientific discovery. We also plan to instate a new section of 'Old Texts Revisited'. Owing to the fact that the context of science, and even more of scientific thought, is constantly changing, the old scientific texts can and certainly should be reinterpreted in the light of our contemporary scientific views, however, without unjustified modernization (see, e.g., Galison, 2008, pp. 122-123).

The journal's visibility: The editorial office also attempts to increase the journal's visibility and popularity by seeking more publicity. Once again, the editors wish to express their gratitude to those who have written about our journal elsewhere. Thus we are especially grateful to Anto Leikola (2013), 
Juozas Algimantas Krikštopaitis and Birutė Railienė (Krikštopaitis \& Railienė, 2014a, b), Jaana Eigi (2014) and Heldur Sander (Sander \& Talts, 2014a, b). The managing editor of $A B H P S$ has also made attempts to introduce the relatively new journal to professional historians (Talts, 2014) and the wider audience in Estonia (Talts, 2015).

Acknowledgements: The journal could not be published without the help of like-minded people, who are earnestly concerned about the journal's future progress. We would like to express our deepest gratitude to Dr. Ramūnas Kondratas from Lithuania for his private donation. In addition, we are very grateful to the Chair of Philosophy of TUT, especially its head, Professor Ahti-Veikko Pietarinen for his financial support, which came in late 2014 when it was needed the most. We would also like to thank Alar Sepp for his supportive attitude toward the development of journal, as well as all the members of the editorial team and the editorial board, who have made their share to improve this journal and thus contribute to the development of entire field of HPS. After all, surveys indicate that the HPS knowledge increases the students' problem-solving abilities even at the earliest stage (e.g., Lin et al., 2002). We are convinced that this is even more true of scientists working in different fields.

On behalf of the editorial office, Peeter Mü̈rsepp and Mait Talts 


\section{References}

Agassi, J. (2014), 'The role of historians in contemporary society,' Acta Baltica Historiae et Philosophiae Scientiarum, vol. 2, no. 2 (Autumn 2014), pp. 3-4. http://dx.doi. org/10.11590/abhps.2014.2.01

Eigi, J. (2014), 'Ühiselt asjade tundmine: objektiivne teadmine ja avalik diskussioon' [Knowing things in common: objective knowledge and public discussion], Sirp: Eesti Kultuurileht, 3 April, p. 18.

Galison, P. (2008), 'Ten problems in history and philosophy of science,' Isis, vol. 99, pp. 111-124.

Krikštopaitis, J. A. \& Railienè, B. (2014a), 'Acta Baltica Historiae et Philosophiae Scientiarum - naujas tarptautinis žurnalas, skirtas mokslo istorijos ir filosofijos problematikai' [Acta Baltica Historiae et Philosophiae Scientiarum - a new international journal dedicated to the problems of history and philosophy of science], Mokslo Lietuva, no. 1 (Sausio 9 d.), p. 5.

(2014b), 'Estijos, Latvijos, Lietuvos filosofų ir istorikų bendradarbiavimo vaisius: Acta Baltica Historiae et Philosophiae Scientiarum' [The result of the cooperation of the philosophers and historians from Estonia, Latvia and Lithuania: Acta Baltica Historiae et Philosophiae Scientiarum], Problemos, no. 85, pp. 232-233.

Leikola, A. (2013), 'Uusi tieteenhistorian lehti Baltiasta' [A new journal on history of science], Tieteessa Tapahtuu, no. 4, p. 39.

Lin, H.-S.; Hung, J.-Y. \& Hung, S.-C. (2002). 'Using the history of science to promote students' problem-solving ability,' International Journal of Science Education, vol. 24, no. 5, pp. 453-464. http://dx.doi.org/10.1080/09500690110073991

Müürsepp, P. \& Talts, M. (2013a), 'Foreword,' Acta Baltica Historiae et Philosophiae Scientiarum, vol. 1, no. 1 (Spring 2013), pp. 3-4.

http://dx.doi.org/10.11590/abhps.2013.1.00

- (2013b), 'Foreword,' Acta Baltica Historiae et Philosophiae Scientiarum, vol. 1, no. 2 (Autumn 2013), pp. 3-4. http://dx.doi.org/10.11590/abhps.2013.2.00

(2014a), 'Foreword,' Acta Baltica Historiae et Philosophiae Scientiarum, vol. 2, no. 1 (Spring 2014), pp. 3-4. http://dx.doi.org/10.11590/abhps.2014.1.00

(2014b), 'Foreword,' Acta Baltica Historiae et Philosophiae Scientiarum, vol. 2, no.2 (Autumn 2014), pp. 3-4. http://dx.doi.org/10.11590/abhps.2014.2.00

Riesch, H. (2014), 'Philosophy, history and sociology of science: interdisciplinary relations and complex social identities,' Studies in History and Philosophy of Science, vol. 48, pp. 30-37. http://dx.doi.org/10.1016/j.shpsa.2014.09.013

Sander, H. \& Talts, M. (2014a), 'Uue teadusloo ajakirja Acta Baltica Historiae et Philosophiae Scientiarum aasta esimene number' [The year's first issue of a new journal on history and philosophy: Acta Baltica Historiae et Philosophiae Scientiarum], Vaba Eesti Sóna (Toronto), 23 May, p. 7. 
Peeter Müürsepp

Mait Talts

(2014b), 'Uuest teaduse ajaloo ja teadusfilosoofia ajakirjast Acta Baltica Historiae et Philosophiae Scientiarum' [On a new journal of history and philosophy of science Acta Baltica Historiae et Philosophiae Scientiarum], Eesti Päevaleht (Stockholm), 25 June, pp. 8-9.

Talts, M. (2014), 'Uuest teaduse ajaloo ja teadusfilosoofia ajakirjast Acta Baltica Historiae et Philosophiae Scientiarum' [The new journal of history and philosophy of science Acta Baltica Historiae et Philosophiae Scientiarum], Tuna: Ajalookultuuri ajakiri, no. 2, pp. 147-149.

(2015), 'Rahvusvaheline, nagu teadus ise' [International as science itself], Horisont, no. 3 (May-June), p. 60. 